\title{
New species and noteworthy findings for flora of the Urals and adjacent territories
}

\author{
N. V. Zolotareva ${ }^{1,10}$, E. N. Podgaevskaya ${ }^{1,11}$, V. A. Glazunov ${ }^{2,12}$, E. D. Lapshina ${ }^{3,13}$, A. S. Tretyakova ${ }^{4,5,14}$, \\ N. Yu. Grudanov $5,4,15$, P. V. Kondratkov, 16, Ya. M. Golovanov ${ }^{6,17}$, N. I. Naumenko ${ }^{7,18}$, A. N. Puzyrev ${ }^{7,}$, \\ S. A. Nikolaenko ${ }^{2,8,20}$, I. V. Filippov ${ }^{3,21}$, D. G. Melnikov ${ }^{9,22 *}$ \\ ${ }^{1}$ Institute of Plant and Animal Ecology, Ural Branch of the Russian Academy of Sciences, \\ 8 Marta str., 202, Yekaterinburg, 620144, Russian Federation
}

${ }^{2}$ Tyumen Scientific Centre, Siberian Branch of the Russian Academy of Sciences, Malygina st., 86, Tyumen, 625026, Russian Federation

${ }^{3}$ Yugra State University, Chekhova st., 16, Khanty-Mansiysk, 628012, Russian Federation

${ }^{4}$ Ural Federal University named after the first President of Russia B. N. Yeltsin, Mira st., 19, Yekaterinburg, 620002, Russian Federation

${ }^{5}$ Institute Botanical Garden of Ural Branch of the Russian Academy of Sciences, 8 March st., 202a, Yekaterinburg, 620144, Russian Federation

${ }^{6}$ South Ural Botanical Garden-Institute of the Ufa Federal Scientific Center of the Russian Academy of Sciences, Mendeleyeva St., 195, build. 3., Ufa, 450080, Russian Federation

${ }^{7}$ Udmurt State University, Universitetskaya str., 1, Izhevsk, 426034, Russian Federation

${ }^{8}$ Papanin Institute for Biology of Inland Waters Russian Academy of Sciences, Yaroslavl Region, Nekouzsky district, v. Borok, 109, 152742, Russian Federation

${ }^{9}$ Komarov Botanical Institute of the Russian Academy of Sciences (BIN RAS), Prof. Popova str., 2, St. Petersburg, 197376, Russian Federation

${ }^{10}$ ORCID iD: https://orcid.org/0000-0003-1895-4681, ${ }^{11}$ ORCID iD: https://orcid.org/0000-0003-2355-5781,

${ }^{12}$ ORCID iD: https://orcid.org/0000-0003-0344-024X, ${ }^{13}$ ORCID iD: https://orcid.org/0000-0001-5571-7787,

${ }^{14}$ ORCID iD: https://orcid.org/0000-0001-8735-4482, ${ }^{15}$ ORCID iD: https://orcid.org/0000-0002-0498-2975,

${ }^{16}$ ORCID iD: https://orcid.org/0000-0001-6472-5455, ${ }^{17}$ ORCID iD: https://orcid.org/0000-0002-4790-8900,

${ }^{18}$ ORCID iD: https://orcid.org/0000-0001-6807-3773, ${ }^{19}$ ORCID iD: https://orcid.org/0000-0003-4969-6355,

${ }^{20}$ ORCID iD: https://orcid.org/0000-0002-4545-9240, ${ }^{21}$ ORCID iD: https://orcid.org/0000-0002-3639-553X

${ }^{22}$ E mail: DMelnikov@binran.ru; ORCID iD: https://orcid.org/0000-0002-9622-2737

* Corresponding author

Keywords: Aktobe Region, Chelyabinsk Region, ecology, Khanty-Mansi Autonomous Area - Yugra, Sverdlovsk Region, taxonomy, Udmurtian Republic.

Summary. The article provides information about rare and newly described species for the flora of the Urals and adjacent territories, namely: Astragalus saphronovae Kulikov, Atraphaxis decipiens Jaub. et Spach., Carex amgunensis F. Schmidt, Galium densiflorum Ledeb., Jovibarba globifera (L.) J. Parn., Najas minor All., Potamogeton nodosus Poir., Pseudorchis albida (L.) Á. Löve et D. Löve, Salix myrsinites L., Veronica agrestis L. Essays include the information on the species ecology and short taxonomic notes. 


\title{
Новые виды и наиболее интересные находки для флоры Урала и прилегающих территорий
}

\author{
Н. В. Золотарева ${ }^{1}$, Е. Н. Подгаевская ${ }^{1}$, В. А. Глазунов ${ }^{2}$, Е. Д. Лапшина ${ }^{3}$, А. С. Третьякова ${ }^{4,5}$, \\ Н. Ю. Груданов ${ }^{5,4}$, П. В. Кондратков ${ }^{4}$, Я. М. Голованов ${ }^{6}$, Н. И. Науменко ${ }^{7}$ А. Н. Пузырев ${ }^{7}$, \\ С. А. Николаенко ${ }^{2,8}$, И. В. Филиппов ${ }^{3}$, Д. Г. Мельников ${ }^{9 *}$
}

\author{
${ }^{1}$ Институт экологии растений и животных Уральского отделения Российской академии наук, \\ ул. 8 Марта, 202, г. Екатеринбург, 620144, Россия \\ ${ }^{2}$ Тюменский научный центр Сибирского отделения Российской академии наук, ул. Мальгина, 86, \\ 2. Тюмень, 625026, Россия \\ ${ }^{3}$ Югорский государственный университет, ул. Чехова, 16, г. Ханты-Мансийск, 628012, Россия \\ ${ }^{4}$ Уральский федеральный университет имени первого Президента России Б. Н. Ельцина, \\ ул. Мира, 19, г. Екатеринбург, 620003, Россия \\ ${ }_{5}^{5}$ Ботанический сад Уральского отделения Российской академии наук, ул. 8 Марта, 202a, \\ г. Екатеринбург, 620144, Россия \\ ${ }^{6}$ Южно-Уральский ботанический сад-институт Уфимского федерального исследовательского \\ иентра Российской академии наук, ул. Менделеева 195, корп. 3, г. Уфа, 450080, Россия \\ ${ }^{7}$ Удмуртский государственный университет, ул. Университетская, 1, г. Ижевск, 426034, Россия \\ ${ }^{8}$ Институт биологии внутренних вод им. И. Д. Папанина Российской академии наук, \\ Ярославская область, Некоузский район, пос. Борок, 109, 152742, Россия \\ ${ }^{9}$ Ботанический институт им. В. Л. Комарова Российской академии наук, \\ ул. Проф. Попова, 2, г. Санкт-Петербург, 197376, Россия \\ * Автор для переписки
}

Ключевые слова: Актюбинская область, Свердловская область, систематика, Удмуртская республика, ХантыМансийский автономный округ - Югра, Челябинская область, экология.

Аннотация. В статье приводятся сведения о произрастании редких и новых видов для флоры Урала и прилегающих территорий: Astragalus saphronovae Kulikov, Atraphaxis decipiens Jaub. et Spach., Carex amgunensis F. Schmidt, Galium densiflorum Ledeb., Jovibarba globifera (L.) J. Parn., Najas minor All., Potamogeton nodosus Poir., Pseudorchis albida (L.) Á.Löve et D.Löve, Salix myrsinites L., Veronica agrestis L. Очерки включают сведения об экологии видов и краткие таксономические заметки.

\section{Introduction}

The flora of the Urals has been studied for a relatively long time. Naturalists of the 18 th century including D. G. Messerschmidt, I. G. Gmelin, G. V. Steller, I. P. Falk, P. S. Pallas, I. I. Lepyokhin and others collected numerous specimens and made seminal floristic observation. The systematic study of the flora of the Urals began in the late 19th - and early 20th centuries; some prominent research scientists of the flora of the Urals during this period were E. Hoffman, F. Ruprecht, V. S. Sergeev, O. E. Kler, P. G. Helm, P. N. Krylov, A. Ya. Gordyagin, S. I. Korzhinsky, P. V. Suizev, I. M. Krascheninnikov, B. N. Gorodkov, V. S.
Govorukhin, P. L. Gorchakovsky and a number of others. The most important summaries on the flora of the Urals are somewhat scant (Krylov, 1927-1939; Goworuchin, 1937; Gorchakovskiy, 1966, 1975; Opredelitel sosudistykh ..., 1994) and havealready outdated in many ways. Thus, a new "Flora of the Urals" is required. In the past two decades, a number of regional "Keys for plant identification" and "Floras" for different subregions of the Urals have appeared, which substantially compensates for this deficiency (for example, Illyustrirovannyy opredelitel ..., 2007; Tarasova, 2007; Martynenko, Gruzdev, 2008; Naumenko, 2008; Ryabinina, Knyazev, 2009; Kulikov, 2010; Baranova, Puzyrev, 2012; etc.). 
Currently, the project "Flora of the Urals and Adjacent Territories" has been launched, its strategies have been defined, and the boundaries of this "Flora" have been outlined in general (Melnikov et al., 2018; Melnikov, 2019). Botanists from all republics, regions and krais (territories) of the study area joined in this project. Within the framework of the "Flora of the Urals", in this article we report on newly described species and noteworthy floristic finds within the Ural region as a whole.

All the species presented in the article are indigenous to the flora of the Urals in general, except for three species, which are adventive for the Sverdlovsk Region (Jovibarba globifera (L.) J. Parn., Potamogeton nodosus Poir., Veronica agrestis L.) and the Udmurtian Republic (V. agrestis).

\section{Materials and methods}

The materials were obtained during expeditionary work and excursions in the period from 2012 to 2020 on the territory of the the Khanty-Mansi Autonomous Area - Yugra, Udmurtian Republic, Sverdlovsk, Chelyabinsk and Aktobe Regions, which are within the boundaries of the planned "Flora of the Urals and adjacent territories" (Melnikov, 2019). The collection of herbarium material was carried out by the route method. The coordinates of the locations were determined by GPS receivers (Garmin series) with an error of up to $100 \mathrm{~m}$; for a number of cases, the coordinates were retrieved from satellite maps of the Yandex service with an error of up to 200 $\mathrm{m}$. Identification of the species was carried out on the basis of modern "Floras" affecting the studied area and taxonomic monographs, for individual species consulted with taxonomists (publications and authors of definitions are indicated in the species essay). Taxa names are given according to "The World Checklist of Vascular Plants" (URL: https://wcvp.science.kew.org), except for cases of disagreement in the interpretation of the taxa status (here we relied on the opinion of the monographs). The cited samples are stored at SUBGI UFSC RAS ${ }^{1}$, UFA $^{2}$, SVER, TMN, UDU, UFU, LE herbaria. The species are arranged in the text alphabetically.

\footnotetext{
${ }^{1}$ South Ural Botanical Garden-Institute of the Ufa Federal Scientific Center of the Russian Academy of Sciences.

${ }^{2}$ Herbarium acronyms are given according to the Index Herbarium database (http://sweetgum.nybg.org/science/ih/).
}

\section{Results and discussion}

\section{New records for the flora of the Urals and Adjacent Territories}

\section{Astragalus saphronovae Kulikov (Fabaceae) \\ Contributor: Ya. M. Golovanov \\ Distribution and habitat}

The species were described from the northern part of the western edge ('chink') of the Ustyurt Plateau, within the Mangistau Oblast of Kazakhstan (Kulikov, 2014), where it grows on fine-earthgravelly slopes as part of agropyreto-artemisetum communities. Until now, it has only been known from the type locality. We found the species in an isolated location $500 \mathrm{~km}$ north of the type locality area at the foot of chalk hills within talus of chalk rocks. It is recorded for the first time within the Aktobe Region of the Republic of Kazakhstan.

\section{Taxonomic notes}

The sect. Cystodes Bunge (syn. Vesicarii DC.), which includes $A$. saphronovae, consists of about 15 species common in Central and South Asia, the Middle East, Western Asia, and Southern Europe (Ghahremani, 2004). In Middle Asia this section initially included two species: A. medius Schrenk and A. albicaulis DC. (Vasilyeva, 1961). Later, this section included $A$. zingeri Korsh., an endemic species for the Middle Volga and Trans-Volga regions (Vasilyeva, 1987). In modern classification of the genus (Podlech, 1999; Sytin, 2009; Podlech, Zarre, 2013), the sect. Cystodes is included in the sect. Dissitiflori DC. (syn. section Xiphidium Bunge). The species of the sect. Cystodes differ from those of the sect. Dissitiflori by a swollen calyx at fruition and the unpressed pubescence of the fruits (Ghahremani, 2004).

A. saphronovae is similar to the desertsteppe species of the same section, which is more widespread in the region - A. medius Schrenk. It differs from it in having much higher, erect, strongly lignified perennial shoots (by the nature of the life form, it is more similar to those of the sect. Dissitiflori, such as A. brachylobus DC. and A. cornutus Pall.), elongated loose racemes (even more elongated in fruiting phase) and particularly in fruit form - much longer and narrower (14-25 mm long and 2.5-3 mm wide) than $A$. medius (10-18 $\mathrm{mm}$ long and 4-5 mm wide), which is a sign of similarity with representatives of the sect. Dissitiflori (Kulikov, 2014). For a number of species (for example, A. zingeri, A. aktiubensis), a hypothesis has been made about their hybrid origin (Kulikov, 2014), 
and in general, for the sect. Dissitiflori, reticulate evolution has been shown (Bartha et al., 2013).

Examined specimens (new record): "Republic of Kazakhstan, Aktobe Region, Khobdinsky district, chalk mountains $16 \mathrm{~km}$ north-east of the village of Zhantalap (324 $\mathrm{m}$ above sea level), $50^{\circ} 24^{\prime} 58.1^{\prime \prime} \mathrm{N}$, 56 3'11.6"E. 21 V 2019. Ya. M. Golovanov". Identified by M. S. Knyazev (Herbarium of SUBGI UFSC RAS, UFA).

\section{Atraphaxis decipiens Jaub. et Spach \\ (Polygonaceae)}

\section{Contributor: N. V. Zolotareva}

\section{Distribution and habitat}

The species was first described from the Kazakh Upland (Kashina, 1992). The main part of the range is concentrated in Kazakhstan (Lovelius, 1978), but the species was also recorded in the Orenburg Region in Sol-Iletskiy, Akbulakskiy (Ryabinina, Knyazev, 2009), Gayskiy, Novosergievskiy, Perevolotskiy districts (data from the SVER herbarium). Within the territory of Siberia, two finds are known in the Russko-Polyansky district of the Omsk Region (Koropachinskiy, Vstovskaya, 2002) and in the Ulug-Khem district of the Republic of Tuva (Shaulo et al., 2006). It grows singularly in steppes on stonygravelly soils (Koropachinskiy, Vstovskaya, 2002), often on chalk outcrops (Ryabinina, Knyazev, 2009), sometimes on gravelly solonetzes (data from the SVER herbarium). It was not previously known from the territory of the Chelyabinsk Region (Kulikov, 2010). The location identified by us is 190 $\mathrm{km}$ northeast of the nearest locality near the village Novopetropavlovka, Gaysky district, Orenburg Region (collection by M. S. Knyazev, SVER). A new species for the flora of the Chelyabinsk Region, the given location is the most northern collection for the region.

\section{Taxonomic notes}

The genus Atraphaxis L. includes about 30 species distributed from the eastern part of the Mediterranean, and from the Balkan Peninsula to Mongolia, but mainly occurs in Middle, Central and Southwest Asia (Lovelius, 1978; Tzvelev, 1996). Within the territory of the Southern Urals in the Orenburg Region, four species of this genus are found, to the north (in the Chelyabinsk Region and the Republic of Bashkortostan) previously only one species was known - A. frutescens (L.) K. Koch (Opredelitel vysshikh ..., 1989; Kulikov, 2010).

A. decipiens differs from $A$. frutescens by having small (5-9 $\mathrm{mm}$ long) and narrow (1-2 $\mathrm{mm}$ wide) linear or linear-lanceolate leaves with revolute margins and inconspicuous lateral veins, short (2$2.5 \mathrm{~cm}$ long) and few-flowered inflorescences, with bright pink sepals at fruition (Ryabinina, Knyazev, 2009; Kulikov, 2010).

Examined specimens (new record): "Chelyabinsk Region, Bredinsky district, left bank of the river Syntasty $3.5 \mathrm{~km}$ north-west of the village of Andreevsky $\left(52^{\circ} 23^{\prime} 36.5^{\prime \prime} \mathrm{N}, \quad 60^{\circ} 44^{\prime} 44.9^{\prime \prime} \mathrm{E}\right)$, poor herboso-festucetum valesiacae steppe in the upper part of the slope of a small hill, on gravelly solonetzes. 14 VI 2020. N. V. Zolotareva" (SVER).

Carex amgunensis F. Schmidt (Cyperaceae)

Contributors: N. V. Zolotareva, E. N. Podgaevskaya

\section{Distribution and habitat}

The species area covers Western and Eastern Siberia, the Far East, Mongolia and Northeastern China (Egorova, 1999), but some relict localities are known from the Urals (Kulikov, 2010; Knyazev et al., 2017). It grows in dry light coniferous (mainly larch and pine) forests at woodland edges, on dry stony and steppe slopes; in the forest belt of mountains, less often on the plains (Egorova, 1999). Until now, no more than five localities were known in the Northern Urals (near the city of Karpinsk and along the Sosva river in the Sverdlovsk Region) (Krasnaya kniga ..., 2018) along with two localities from the South Urals (in the Miass and Karabash urban districts of the Chelyabinsk Region) (Krasnaya kniga ..., 2017a). In the Middle Urals, the species was recorded for the first time. The location identified by us is located $130 \mathrm{~km}$ north of the nearest locality on Shigirskiye Sopki near the village of Slyudorudnik, Karabash urban district of the Chelyabinsk Region (Krasnaya kniga ..., 2017a).

\section{Taxonomic notes}

Carex amgunensis is within sect. Acrocystis Dumort. This section includes about 45 species, of which 17 are found in Europe and Asia, about 25 species are endemic to North America and one to South America (Egorova, 1999). In the flora of the Urals, the section includes five species (Egorova, 1999; Kulikov, 2010; Knyazev et al., 2017), of which $C$. amgunensis is closest to $C$. ericetorum Pollich, but it is well distinguished by a short (0.6$0.8(1) \mathrm{cm}$ long) and narrow-linear (1-2 mm wide) few-flowered staminate spikelet, spherical pistillate spikelets ( $0.5 \mathrm{~cm}$ long), of which the upper is located on the same level with the staminate spikelet, larger perigynia (3.5-4(4.5) $\mathrm{mm}$ long) each with an 
elongated beak (1-1.2 mm long), narrower (1.5-2 $\mathrm{mm}$ wide) and softer leaf blades and purple-brown sheaths (Kulikov, 2010).

Examined specimens (new records): "Sverdlovsk Region, Yekaterinburg city, environs of the Palkino railway station, granite rocks «Kamennaya Chasha», $56^{\circ} 51^{\prime} 59.6^{\prime \prime} \mathrm{N}$, $60^{\circ} 22^{\prime} 48.8^{\prime \prime} \mathrm{E}$, under the rocks. 18 VII 2020. N. V. Zolotareva, E. N. Podgaevskaya" (SVER); the same city, "environs of the Severka settlement, outcrops of the Severskie Rocks granites $\left(56^{\circ} 51^{\prime} 50.5^{\prime \prime} \mathrm{N}\right.$, $60^{\circ} 18^{\prime} 26.5^{\prime \prime} \mathrm{E}$ ), under the rocks. 17 VII 2020. N. Zolotareva, E. N. Podgaevskaya" (SVER).

Galium densiflorum Ledeb. (Rubiaceae)

\section{Contributor: V. A. Glazunov}

\section{Distribution and habitat}

The species is distributed in the Arctic from the northern Malozemelskaya tundra in the west to Chukotka in the East (including the Polar Urals, Yamal), in the southeast of Western Siberia (including Altai), in Central and Eastern Siberia, in Eastern Kazakhstan, in the Far East, Mongolia and China (var. saurense (Litvinov) Tzvelev pubescent variety) (Igoshina, 1966; Naumova, 1996; Rastitelnyy pokrov ..., 2006; Pinzhenina, 2020; Galium densiflorum ..., 2021).

It grows in the lower zones of alpine areas on stony slopes, rocks and in the lower zones in open steppe meadows, among bushes, river banks and flooded meadows (Krylov, 1939; Pobedimova, 1978; Naumova, 1996). The species is characterized by habitats with a periodic deficit of moisture in the soil, although it also occurs on moderately humid dry-meadow areas of the slopes of river terraces and high floodplain (Tzvelev, 1987). N. N. Tzvelev $(1986,1987)$ assigned it to the group of arcticmontane species.

This is the first find in the Subpolar Urals and the southernmost in the Urals (the distance to the nearest find in the Polar Urals is about $240 \mathrm{~km}$ ). A new species for the Khanty-Mansi Autonomous Area - Yugra.

\section{Taxonomic notes}

G. densiflorum is part of the type section (sect. Galium) and belongs to the relationship of G. verum L. and G. ruthenicum Willd., G. wirtgenii F. W. Schultz (Pobedimova, 1958, 1978; Ehrendorfer et al., 1976; Tzvelev, 1986). The aggregate G. verum is sometimes considered as one species ( $G$. verum s. 1.) (Ehrendorfer et al., 1976) with several subspecies, and G. densiflorum, G. wirtgenii and G. ruthenicum are treated as synonyms, or at least questionable taxa. However, recent studies of this group showed the stability of a number of morphological characters in the above species. G. densiflorum differs from $G$. verum and $G$. ruthenicum by having a very narrow paniculate inflorescence, leaves with revolute margins, the lower branches of the inflorescence, which are shorter than the internodes and equal to the leaves that are not reduced in the inflorescence, in having styles split to $3 / 4$ of its length (in G. verum, the style is bipartite and split to the very base, in $G$. ruthenicum and $G$. wirtgenii, the styles are split only to the middle), and differs from $G$. wirtgenii in densely hairy ovaries and fruits (Pobedimova, 1958; Tzvelev, 1986; Pinzhenina (Balde), 2014).

Examined specimens (new record): "KhantyMansi Autonomous Area - Yugra. Subpolar Urals, north of the river Tykotlova, $65^{\circ} 17^{\prime} 54.6^{\prime \prime} \mathrm{N}$, $62^{\circ} 5^{\prime} 4.5^{\prime \prime} \mathrm{E}$, on a carbonate rock, solitary, blooming. 12 VII 2018. V. A. Glazunov" (TMN).

Jovibarba globifera (L.) J. Parn. s. str. (Sempervivum globiferum L.) (Crassulaceae)

Contributors: N. V. Zolotareva, E. N. Podgaevskaya

\section{Distribution and habitat}

The species occurs in Central and Eastern Europe, from central Germany to the eastern Carpathians, in the west and northwest of the European part of Russia (Favarger et al., 1993). The eastern limit of the species range passes through the Nizhny Novgorod and Penza Regions, where single localities have been documented, and the species is included in the regional Red Data Books (Krasnaya kniga ..., 2013, 2017b; Vasjukov, Saksonov, 2020). Further, east to the Urals, there are no natural localities of the species: in the Samara, Ulyanovsk Regions and Republic of Mordovia it is cultivated as an ornamental plant (Plantae vasculares ..., 2010; Saksonov, Senator, 2012; Rakov et al., 2014), in the flora of Chuvash Republic, Republic of Tatarstan, Republic of Mari El, Udmurtian Republic, Kirov Region it is absent (Abramov, 1995; Bakin et al., 2000; Tarasova, 2007; Baranova, Puzyrev, 2012; Gafurova, 2014). In the Urals, the species was not previously recorded either, representatives of the genus Jovibarba Opiz are absent in the flora of the Sverdlovsk, Chelyabinsk and Orenburg Regions, Perm Territory, Republic of Bashkortostan (Opredelitel vysshikh ..., 1989; Kulikov, 2005; Illyustrirovannyy opredelitel ..., 2007; Ryabinina, Knyazev, 2009; Knyazev et al., 2019). In the primary area, it grows on dry sandy soils, carbonate outcrops, pine forests and dry meadows (Favarger et al., 1993; 
Bjalt, 2001). The location of the species identified by us is probably associated with its escape from cultivation - collective gardens are located $0.5 \mathrm{~km}$ away. A new species and genus for the flora of the Sverdlovsk Region, as well as for the territory of the Urals.

\section{Taxonomic notes}

The genus Jovibarba Opiz includes from two to six species (depending on the understanding of the volume of the species) in Central, Eastern and Southern Europe (Favarger et al., 1993; Bjalt, 2001). In the flora of the Urals, J. globifera is morphologically closest to species of the genus Orostachys Fisch., from which it differs in the presence of stolons and the absence of a spinule on the tops of leaves (in J. globifera, the leaves are ciliate along the margin) (Bjalt, 2001; Kulikov, 2010).

Examined specimens (new record): "Sverdlovsk Region, Yekaterinburg city, environs of the railway Palkino station, right bank of Reshetka River $\left(56^{\circ} 52^{\prime} 5.3^{\prime \prime} \mathrm{N}, 60^{\circ} 22^{\prime} 30.1^{\prime \prime} \mathrm{E}\right)$, small outcrops of granite surrounded by a herboso-calamagrostietum epigei meadow. 18 VII 2020. N. V. Zolotareva, E. N. Podgaevskaya" (SVER).

Najas minor All. (Caulinia minor (All.) Coss. et Germ.) (Hydrocharitaceae)

Contributors: N. Yu. Grudanov, A. S. Tretyakova

\section{Distribution and habitat}

Najas minor is an indigenous Eurasian southern boreal forest-steppe species. It is found in Western, Central, Northern (south) and Eastern (south, including the Caucasus) Europe, North Africa, Western (Turkey, Syria, Lebanon, Iran, Iraq), Middle (Kazakhstan and Uzbekistan), Central (Afghanistan, Pakistan), South (northern India) and East (China, Korean Peninsula, Japan) Asia, southern regions of Siberia and the Far East. It is an invasive species in North America (Merkulowicz, 1941; Tzvelev, 1979; Triest, 1988; Conspectus florae ..., 2005; Najas minor ..., 2021). Within the territory of the region, the species was collected in the 19th century in the Perm Region (in the cities of Perm and Ocher; Suizev, 1912; Goworuchin, 1937; Ovesnov, 1997), in the Tyumen Region lake Gryaznoe to the north of the village Peganovo, Berdyuzhsky district; lake Aiginskoye, 9 km northeast of the village Shcherbak; lake Kuchakovo, Nizhnetavdinsky District (Khozyainova, Glazunov, 2001; Zasukha, Likhovidova, 2001; Naumenko et al., 2011; Glazunov, Nikolaenko, 2015). This species is presented for the first time in the Sverdovsk Region. It is an annual that reproduces exclusively by seeds. Seed transfer is carried out by hydrochoria, as well as by endo- and epiozoochory (Triest, 1988; Birykova et al., 2017). It occurs in shallow, relatively warm stagnant water bodies (floodplain lakes, river backwaters, less often mainland lakes and ponds) but can also grow in streams and rivers. $N$. minor prefers an alkaline condition $(\mathrm{pH}$ 6.0-9.3 with an optimal range of about 6.6-7.2). It occurs at a depth of up to $5 \mathrm{~m}$ with an optimum of about $0.5-2 \mathrm{~m}$ and temperatures up to $8{ }^{\circ} \mathrm{C}$, and can inhabit brackish waters with salinity up to $0.3 \mathrm{ppt}$ (Krasnaya kniga ..., 2008; Global Invasive ..., 2013). There are conflicting opinions regarding the turbidity of water and its eutrophication. So, for the Tyumen Region, it is indicated (Kapitonova, 2017) that the species is characterized by low competitiveness, does not withstand water pollution or turbidity, while for the USA, it is indicated that it is resistant to turbidity and eutrophication, and this gives it competitive advantages and contributes to the replacement of native species (Global Invasive ..., 2013). Considering its relict nature (Birykova et al., 2017) and its extremely rare localities in the Ural region, it can be agreed that the species is at the limit of its ecological range.

\section{Taxonomic notes}

$N$. minor belongs to the subgenus Caulinia (Willd.) A. Br. ex Rendle (considered by some authors as part of the independent genus Caulinia Willd. (Tikhomirov, 2015)), in sect. Euvaginatae Magnus. It differs from the similar species $N$. flexilis (Willd.) Rostk. et W. L. E. Schmidt (from sect. Americanae Magnus) by having leaves suddenly (rather than gradually) narrowed towards the base of the blade, brittle leaves (rather than flexible), narrower leaf blades $(0.3-0.5 \mathrm{~mm}$ wide, excluding the teeth, not $0.4-1.2 \mathrm{~mm}$ wide) with spaced teeth along the edge, narrower (about $0.5 \mathrm{~mm}$ wide, not $0.6-0.8 \mathrm{~mm}$ wide) fruits, a seed envelope with a clearly visible sculpture of rectangular cells (but not with a smooth surface) (Kulikov, 2010). In the Far East (Eastern China, Japan) and in South Asia (northern India, Nepal), it is replaced by the closely related species $N$. oguraensis Miki. $N$. minor differs from the latter species in having single-sporangiate (rather than tetra-sporangiate) anthers $0.56-1.3 \mathrm{~mm}$ long ( $N$. oguraensis $1.3-1.8 \mathrm{~mm}$ long), seeds 1.74 $2.74 \mathrm{~mm}$ long (in $N$. oguraensis $2.6-3.5 \mathrm{~mm}$ long) and, on average, two times smaller epidermal cells of the leaf and slightly smaller leaf sizes $(6.5-35 \mathrm{~mm}$ long, $0.13-0.7 \mathrm{~mm}$ wide in $N$. minor and $7-43 \mathrm{~mm}$ 
long, 0.1-0.66 mm wide in $N$. oguraensis) (Triest, 1988; Midorikawa et al., 2020). N. minor is highly variable in leaf shape, especially in the length of the leaf teeth. In some Asian specimens, the midrib is spiked on the underside of the leaf (for example, Litwinow 3118 (LE)) (Triest, 1988).

Examined specimens (new record): "Russia, Sverdlovsk Region, Sukholozhsky district, the vicinity of Reftinsky village, warm waters of the Reftinskaya SDPP [State District Power Plant], $57^{\circ} 06^{\prime} 01.4^{\prime \prime} \mathrm{N}, 61^{\circ} 43^{\prime} 09.7^{\prime \prime E}$. 24 VIII 2019. N. Yu. Grudanov, A. S. Tretyakova" (UFU).

Ortilia obtusata (Turcz.) H. Hara (Pyrolaceae)

Contributor: N. I. Naumenko

\section{Distribution and habitat}

O. obtusata is a predominantly mountain forest and tundra species (Kobeleva, 1977) distributed in the mountain forests of Siberia (east of Western Siberia, Central and Eastern Siberia, the Northern Urals and the European Arctic (Busch, 1952); also indicated from the mountainous regions of the Caucasus and Central Asia, Mongolia, Tibet, the Himalayas, and North America (Skvortsov, 1980, 1981; Malyschev, 1997). Within the territory of the European part of Russia, the species is documented from the Arctic and Dvino-Pechersk floristic regions (Skvortsov, 1960, 1981). It grows in light greenmoss and herb-green-moss coniferous and mixed forests, herbaceous and shrub tundras, in subalpine meadows, occurs not only on acidic, but also on basic and medium silicate rocks, calcareous sandstones and shales (Skvortsov, 1980; Malyschev, 1997). For the territory of the Udmurtian Republic, it was not previously documented (Baranova, Puzyrev, 2012). The location identified by us represents a significant separation (about $500 \mathrm{~km}$ to the south) from the southern boundary of the species distribution in the European part of Russia $\left(60-65^{\circ} \mathrm{N}\right)$, as well as from known localities on the eastern slope of the Urals in the Sverdlovsk Region (about $440 \mathrm{~km}$ to southwest) (Skvortsov, 1960; Knyazev et al., 2018). A new species for the flora of the Udmurtian Republic, the given location is the most southern for the region.

\section{Taxonomic notes}

The genus Ortilia Rafin. includes two or three species (depending on the point of view on the volume of the species): O. secunda (L.) House, O. kareliniana (A. K. Skvortsov) Holub, and O. obtusata, which have a boreal Holarctic range (Skvortsov, 1960, 1980), common in the Arctic and temperate forest areas of the mountains and plains of the Northern Hemisphere. Within the boundaries of the Udmurtian Republic and the adjacent regions of the Urals and the Cis-Urals, only one species was previously known - O. secunda ( Illyustrirovannyy opredelitel ..., 2007; Baranova, Puzyrev, 2012), which is widespread in the lowland forests of Eurasia (Busch, 1952).

It is described in the rank of variety (Pyrola secunda (L.) Garcke var. obtusata Turcz.) by N. S. Turczaninow from Tunkinskiye Goltsy (Eastern Siberia). O. obtusata is taxonomically closer to $O$. kareliniana. It differs from $O$. secunda in the noticeably smaller size of the plant: stems $3-15 \mathrm{~cm}$ high; opaque, dark green above and light below, broadly ovate, oval or rounded, rounded at the top of the leaves $1-2.5 \mathrm{~cm}$ long and $1-2 \mathrm{~cm}$ wide (O. secunda leaves slightly glossy, green, almost monochromatic above and below, ovoid, pointed, $2-5 \mathrm{~cm}$ long and $1-4 \mathrm{~cm}$ wide), as well as shorter (1.5-4 cm long), open, few-flowered inflorescences with 4-5 (up to 10) flowers per raceme (O. secunda has up to 25 flowers per raceme).

Comparison with herbarium material from Eastern Siberia (LE, LECB) confirmed the conspecificity of the samples from the Udmurtian Republic to the samples of $O$. obtusata.

Examined specimens (new records): "Udmurtian Republic, Kezsky district, environs of the village of Guleishur $\left(57^{\circ} 48^{\prime} 31.4^{\prime \prime} \mathrm{N}\right.$, $\left.53^{\circ} 22^{\prime} 13.8^{\prime \prime} \mathrm{E}\right)$, sphagnum pine forest in the valley of the river Cheptsa. 25 VII 2019. N. I. Naumenko, A. N. Puzyrev" (UDU); "Udmurtian Republic, Kezsky district, environs of the village Malyy Polom $\left(57^{\circ} 44^{\prime} 52.2^{\prime \prime} \mathrm{N}, 53^{\circ} 29^{\prime} 25.7^{\prime \prime} \mathrm{E}\right)$, sphagnum swamp forest. 06 VIII 2020. N. I. Naumenko, A. N. Puzyrev" (UDU).

Potamogeton nodosus Poir. (Potamogetonaceae) Contributors: N. Yu. Grudanov, A. S. Tretyakova.

\section{Distribution and habitat}

The species has a rather extensive area. It is distributed in Europe to the north to the Baltic and North Seas and to the taiga zone, in Africa, in Anterior, Middle, Central, South and Southeast Asia, North, Central and South America, in the north and west of Australia (Dandy, 1980; Kaplan, Symoens, 2005; Potamogeton nodosus ..., 2021). This species occurs in water bodies and streams with slightly alkaline water rich in minerals (Kaplan, Symoens, 2005).

In the European part of Russia, it grows mainly in the chernozem zone, but in recent decades, the species began to expand its area in northern and 
northeastern directions (Shcherbakov et al., 2008; Mayevskiy, 2014). For the Sverdlovsk Region, this is the first documented occurence (Opredelitel sosudistykh ..., 1994; Knyazev et al., 2017). Apparently, the species is adventive in the region, because it is significantly (over $550 \mathrm{~km}$ ) north of the known localities in the Orenburg Region (Ryabinina, Knyazev, 2009), does not occur in the adjacent areas of the Kurgan and Chelyabinsk Regions (Ovesnov, 1997; Naumenko, 2008; Kulikov, 2010), and only occurs in the unnaturally warm water of the Reftinskaya SDPP in the studied region. For the Middle Urals, this species is presented for the first time.

\section{Taxonomic notes}

It differs from the similar $P$. natans $\mathrm{L}$. in the absence of a mobile, usually pale, articulation of the petiole and leaf blade, submerged leaves with a developed lanceolate translucent leaf blade (and not reduced to the petiole), shorter fruitlets (up to 4.2 mm long), a well-marked sharp keel, and a straight (rather than curved) stylodium (Dandy, 1980; Lisitsyna et al., 2009).

Examined specimens (new record): "Sverdlovsk Region, Sukholozhsky district, the vicinity of of Reftinsky village, discharge channel of the Reftinskaya SDPP, in the water near the coast $\left(57^{\circ} 06^{\prime} 01.4^{\prime \prime} \mathrm{N}, 61^{\circ} 43^{\prime} 09.7^{\prime \prime} \mathrm{E}\right) .24$ VII 2019. N. Yu. Grudanov" (UFU).

Pseudorchis albida (L.) Á. Löve et D. Löve (Leucorchis albida (L.) E. Mey.) (Orchidaceae)

Contributors: E. D. Lapshina, V. A. Glazunov Distribution and habitat

Distributed in the east of North America, in Greenland, in Western and Central Europe (mainly in mountainous areas such as the Alps, Pyrenees, south of the Dinaric Highlands) and Northern Europe (British Isles, Fennoscandia), Iceland, in the northern regions of Eastern Europe (Murmansk, Arkhangelsk, Vologda Regions, the Komi Republic), in the north of the Urals and Western Siberia (Moore, 1980; Pseudorchis albida ..., 2021). In the Urals, it is the rare species and is recorded in the northern taiga and tundra zone of the Subpolar and Polar Urals and the Cis-Urals area (from the lower reaches of the Pechora to the upper reaches of the Vychegda (Mamayev et al., 2004). The nearest location is known from the vicinity of the village of Neroyka (Khanty-Mansi Autonomous Area - Yugra) (Korikova, Tyurin, 2018), 140 km south-west of the new find, and another locality has been documented over $200 \mathrm{~km}$ south-south- west of this find in the Northern Urals, in the upper reaches of the Volya River (Tyurin, Baykalova, 2012). It grows in a wide range of soil conditions: from acidic waterlogged substrates of sphagnum bogs to alkaline drained soils on gypsum karsts (Jersáková et al., 2011; Varlygina et al., 2014). In the Urals, it occurs in sparse coniferous and birch forests, forest edges, damp and swampy meadows, and in mountain tundra (Mamayev et al., 2004). The species is significantly reduced in abundance almost throughout its area (Jersáková et al., 2011). It is included in the Red Data Book of the KhantyMansi Autonomous Area - Yugra (Krasnaya kniga ..., 2013) with status 2 and in the Red Data Book of the Komi Republic (Krasnaya kniga ..., 2019) with status 3 .

\section{Taxonomic notes}

Monotypic (or oligotypic) genus. Sometimes a closely related species $P$. straminea (Fernald) Soják is recognized (Bateman et al., 2017), whose populations in Northern Europe clearly differ from P. albida, but to the south, the morphological boundaries between them are erased (the differences are mainly in dimensional characters). Thus, it has been proposed to consider these two taxa as morphotypes of the same species (Varlygina et al., 2014). However, Bateman et al. (2017) consider the smaller sizes of plant organs from northern populations as adaptive characters to the habitat and the populations attributed to $P$. straminea as a young sister species.

Examined specimens (new records): "KhantyMansi Autonomous Area - Yugra. Subpolar Urals, north of the river Tykotlova, $65^{\circ} 18^{\prime} 19^{\prime \prime} \mathrm{N}, 62^{\circ} 8^{\prime} 15^{\prime \prime} \mathrm{E}$, spruce-cedar-birch subshrub-green moss forest, solitary, 12 VII 2018, E. D. Lapshina" (TMN); ibid.,

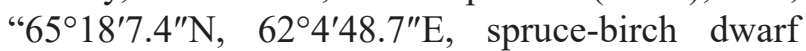
birch-green moss-sphagnum forest, solitary. 12 VII 2018. V. A. Glazunov" (TMN).

\section{Salix myrsinites L.}

\section{Contributor: V. A. Glazunov}

\section{Distribution and habitat}

The species is common in Western, Northern and Eastern (north and north-east) (north of Great Britain, Fennoscandia, Kola Peninsula and north of Karelia, Bolshezemelskaya tundra, in the Northern, Subpolar and Polar Urals) Europe and Western Siberia (eastern slope of the Polar Urals) (Belyaeva et al., 2006; Rastitelnyy pokrov ..., 2006; Salix myrsinites ..., 2021). Within the administrative boundaries in the Urals, it is found in the Sverdlovsk Region, the Komi Republic and the Yamalo-Nenets 
Autonomous Area. It prefers basic rocks, mostly on limestones, on well-moistened substrates along banks of streams, on swamp outskirts, hollows, and on conglomerations of boulders (Skvortzov, 1966; Belyaeva et al., 2006). This find is a new species for the Khanty-Mansi Autonomous Area - Yugra.

\section{Taxonomic notes}

A. K. Skvortzov (1966) considered populations from the Pyrenees, Alps and Carpathians as independent species (S. breviserrata Flod., S. alpina Scop.). In the south of Siberia (Altai, Sayany, Sokhondo, Barguzinsky ridge), S. myrsinites is replaced by a closely related species $S$. rectijulis Ledeb. The latter species is distinguished by the falling leaves of the last season, rather than remaining on the shoots. (Skvortsov, 1999).

Examined specimens (new record): "KhantyMansi Autonomous Area - Yugra. Subpolar Urals, north of the river Tykotlova, $65^{\circ} 17^{\prime} 34^{\prime \prime} \mathrm{N}, 62^{\circ} 8^{\prime} 44^{\prime \prime} \mathrm{E}$, along streambank, abundant. 10 VII 2018. V. A. Glazunov" (definition confirmed by I. V. Belyaeva) (TMN).

\section{Veronica agrestis $\mathrm{L}$.}

Contributors: A. N. Puzyrev, N. Yu. Grudanov, P. V. Kondratkov, A. S. Tretyakova

\section{Distribution and habitat}

$V$. argestis is distributed mainly in Western and Central Europe, avoids the extreme northern territories, and is a rather rare invasive species for many areas of the world including Eastern Europe (Baltics, Belarus, Ukraine, Nord, Central and South Russian regions), the Caucasus, Iran, Siberia, Eastern China, North and South America, South Africa, Australia, and New Zealand (Flora Nizhnego Dona ..., 1985; Tabaka et al., 1988; Mosyakin, Fedoronchuk, 1999; Opredelitel vysshikh ..., 1999; Mayevskiy, 2014; Veronica agrestis ..., 2021).

There is one indication for Siberia in the city of Tomsk (Kosachev, Ebel, 2010). For the flora of the Ural region, only one find is indicated each for the Republic of Bashkortostan in the Ufa city (Noskov, 1931, cited in Muldashev et al., 2017), for the Chelyabinsk Region in Solnechny settlement (Kulikov, 2010), for the Perm Territory (Illyustrirovannyy opredelitel ..., 2007). These are the first collection of this species from the territory of the Sverdlovsk Region and the Udmurtian Republic.

\section{Taxonomic notes}

$V$. agrestis is a ruderal-segetal annual plant, belongs to the subgenus Pocilla (Dumort.) MartínezOrtega, Albach et Fischer. The species complex of $V$. agrestis, $V$. opaca Fr. and V. polita Fr. is consid- ered as sibling species. It differs from $V$. opaca and $V$. polita in the absence of simple hairs in the pubescence of the capsule (only glandular hairs are present), in a whitish, pale blue or pinkish corolla (in $V$. opaca and $V$. polita, corollas are generally bright blue), from $V$. opaca, it differs in less pubescent sepals, an obcordate capsule (in $V$. opaca, it is obreniform), and from $V$. polita - in lanceolate obtuse rather than ovoid acicular sepals (Drabble, Little, 1931; Walters, Webb, 1972; Yelenevsky, 1978). $V$. agrestis, unlike the other two species, is a tetraploid $(2 n=28)$, not a diploid.

Examined specimens (new records): "Udmurtian Republic, Sharkansky district, Lyalshur village, in the courtyard of the Lyalshur secondary school. On a flower garden near the school building, widely, blooms, bears fruit. 30 VII 2012. A. N. Puzyrev, Yu. N. Batanogova" (UDU); "Udmurtian Republic, Yakshur-Bodya district, village Yakshur-Bodya, on a flower garden near the building of an elementary school opposite the bus station. 15 VIII 2013. A. N. Puzyrev, N. A. Prozorova" (UDU); Ibid., "Weed on the flower garden, on the paths and in the crevice at the edge of the sidewalk. 21 VIII 2014. A. N. Puzyrev, N. A. Prozorova" (UDU); "Udmurtian Republic, Uvinsky district, the village of Novy Multan, in the courtyard of the Novomultan special correctional general education residential school of the VIII type. In the gap at the sidewalk, near the flower garden, several specimens. 22 VIII 2015. A. N. Puzyrev, K. N. Lipina" (UDU); Ibid. "In planting beets, widely. 22 VIII 2015. A. N. Puzyrev, K. N. Lipina" (UDU, LE); Ibid. "Weed on the flower garden near the school building, widely. 22 VIII 2015. A. N. Puzyrev, K. N. Lipina" (UDU, LE); Ibid. "In planting beets, often. 22 VIII 2015. A. N. Puzyrev, K. N. Lipina" (UDU); "Udmurt Republic, village of Yakshur-Bodya, in courtyard of a secondary school (Pushinoy str., 61), near the building of an elementary school. On a flower garden among Lobularia and other ornamental plants. 09 VIII 2016. A. N. Puzyrev, N. A. Prozorova" (UDU, LE); "Udmurtian Republic, the city of Votkinsk, in the courtyard of the ecological and biological center (Chaikovskogo str., 6). Weed in the orchard, near the compost heap. 24 VIII 2017. A. N. Puzyrev, E. N. Baralgina" (UDU); Ibid. "On the path between planting onions. 24 VIII 2017. A. N. Puzyrev, E. N. Baralgina" (UDU); "Sverdlovsk Region, Alapaevsky district, the vicinity of the village Novoyamovo, sowing peas $\left(59^{\circ} 54^{\prime} 46.3^{\prime \prime} \mathrm{N}, 61^{\circ} 43^{\prime} 23.7^{\prime \prime} \mathrm{E}\right) .26$ VII 2019. N. Yu. Grudanov, P. V. Kondratkov, A. S. Tretyakova" (UFU). 


\section{Conclusions}

In the course of the studies carried out in some regions of the Urals and adjacent territories, a number of rare and new species for these territories were discovered: Astragalus saphronovae Kulikov, Atraphaxis decipiens Jaub. et Spach., Carex amgunensis F. Schmidt, Galium densiflorum Ledeb., Jovibarba globifera (L.) J. Parn., Najas minor All., Potamogeton nodosus Poir., Pseudorchis albida (L.) Á. Löve et D. Löve, Salix myrsinites L., Veronica agrestis L. The materials will be useful for maintaining the Red Data Books and floristic lists of the Aktobe, Sverdlovsk and Chelyabinsk Regions, as well as for the Udmurtian Republic and KhantyMansi Autonomous Area.

\section{Acknowledgments}

We express our gratitude to Doctors of Biology M. S. Knyazev and I. V. Belyaeva for advice and assistance in determining herbarium specimens.

The work was supported by the state assignments: AAAA-A19-119031290052-1 "Sosudistye rasteniia Evrazii: sistematika, flora, rastitel'nye resursy" ["Vascular plants of Eurasia: systematics, flora, plant resources"], AAAA-A18-118011990151-7 "Izucheniye, sokhraneniye i rasshireniye bioraznoobraziya rasteniy v prirode i pri introduktsii na Yuzh nom Urale i Priuralye" ["Study, conservation and expansion of plant biodiversity in nature and during introduction in the Southern Urals and the Cis- and Trans-Urals region"], AAAA-A 17-117050400146-5 "Otsenka prostranstvennovremennoy izmenchivosti bioraznoobraziya i usloviy yego formirovaniya na Severe Zapadnoy Sibiri v svyazi s izmeneniyem klimata i osvoyeniyem neftegazovykh resursov" ["Assessment of the spatio-temporal variability of biodiversity and the conditions for its formation in the north of Western Siberia in connection with climate change and the development of oil and gas resources"], and by "Programmoy povysheniya konkurentosposobnosti Uralskogo federalnogo universiteta" ["The program for improving the competitiveness of the Ural Federal University"] (the decree no. 211 of the Government of the Russian Federation, contract no. 02.A03.21.0006).

The finds of species in the Khanty-Mansi Autonomous Area - Yugra were made during the research for the regional Red Data Book.

\section{REFERENCES / ЛИTEPATУPA}

Abramov N. V. 1995. Konspekt flory Respubliki Mariy El [Synopsis of the flora of the Republic of Mari El]. Yoshkar-Ola: Mari State University Press. 192 pp. [In Russian] (Абрамов Н. В. Конспект флоры Республики Марий Эл. Йошкар-Ола: МарГУ, 1995. 192 с.).

Baranova O. G., Puzyrev A. N. 2012. Conspectus florae provinciae Udmurtiensis (plantae vasculares). Moscow, Izhevsk: Institute for Computer Research. 212 pp. [In Russian] (Баранова О. Г., Пузырев А. Н. Конспект флоры Удмуртской Республики (сосудистые растения): монография. М.-Ижевск: Институт компьютерных исследований, 2012. 212 с.).

Bakin O. V., Rogova T. V., Sitnikov A. P. 2000. Sosudistyye rasteniya Tatarstana [Vascular plants of Tatarstan]. Kazan: Kazan University Publishing House. 496 pp. [In Russian] (Бакин О. В., Рогова Т. В., Ситников А. П. Сосудистые растения Татарстана. Казань: Изд-во Казанского университета, 2000. 496 с.).

Bartha L., Dragoş N., Molnár V. A., Sramkó G. 2013. Molecular evidence for reticulate speciation in Astragalus (Fabaceae) as revealed by a case study from sect. Dissitiflori. Botany 91(10): 702-714. DOI: 10.1139/cjb-2013-0036

Bateman R. M., Rudall R. J., Denholm I. 2017. Morphometric comparison of British Pseudorchis albida with Icelandic P. straminea (Orchidaceae: Orchidinae). New Journal of Botany 7(2-3): 78-93. DOI: 10.1080/20423489.2017.1408191

Belyaeva I. V., Epanchintseva O. V., Shatalina A. A., Semkina L. A. 2006. Willows of Ural: atlas and identification key. Yekaterinburg: UB RAS. 174 pp. [In Russian] (Беляева И. В., Епанчинцева О. В., Шаталина А. А., Семкина Л. А. Ивы Урала: атлас-определитель. Екатеринбург: УрО РАН, 2006. 174 с.).

Birykova O. V., Schestakova A. A., Belyakov E. A., Garin E. V. 2017. On the distribution of Caulinia minor (All.) Coss. et Germ. (Hydrocaritaceae, Liliopsida) on the territory of the Nizhny Novgorod region. Povolzhskiy Journal of Ecology 3: 251-259. DOI: 10.18500/1684-7318-2017-3-251-259

Bjalt V. V. 2001. Jovibarba Opiz In: Flora Europae orientalis. T. 10. Magnoliophyta (=Angiospermae). N. N. Tzvelev (Ed.). Petropoli: Mir i Semia. Pp. 257-259. [In Russian] (Бялт В. В. Бородник - Јоvibarba Орiz // Флора Восточной Европы. Т. 10. Под ред. Н. Н. Цвелева. СПб: Мир и семья, 2001. С. 257-259).

Busch N. A. 1952. Pyrolaceae Lindl. In: Flora USSR. T. XVIII. B. K. Schischkin, E. G. Bobrov (eds). Moscow, Leningrad. Editio Academiae scientiarum URSS. Pp. 7-19. [In Russian] (Буи Н. А. Сем. Грушанковые-Pyrolaceae Lindl. // Флора СССР. Т. 18. М.-Л.: Изд-во АН СССР, 1952. С. 7-19). 
Conspectus florae Sibiriae: plantae vasculares. 2005. K. S. Baikov (Ed.). Novosibirsk: Nauka. 362 pp. [In Rissian] (Конспект флоры Сибири: Сосудистые растения. Под ред. К. С. Байкова. Новосибирск: Наука, 2005.362 с.).

Dandy J. E. 1980. Potamogeton L. In: Flora Europaea. Vol. 5. Alismataceae to Orchidaceae (Monocotyledones). T. G. Tutin, V. H. Heywood, N. A. Burges, D. M. Moore, D. H. Valentine, S. M. Walters, D. A. Webb (eds). Cambridge: Cambridge University Press. Pp. 7-11.

Drabble E., Little J. E. 1931. The british Veronicas of the Agrestis group. The Journal of Botany British and Foreign. 69: 180-185, 201-205.

Ehrendorfer F., Krendl F., Puff Ch. 1976. Galium L. In: Flora Europaea. Vol. 4. Plantaginaceae to Compositae (and Rubiaceae). T. G. Tutin, V. H. Heywood, N. A. Burges, D. M. Moore, D. H. Valentine, S. M. Walters, D. A. Webb (eds). Cambridge: Cambridge Unversity Press. Pp. 14-36.

Egorova T. V. 1999. The Sadges (Carex L.) of Russia and adjacent states (within the limits of the former USSR). A. L. Takhtajan (Ed.). St.-Petersburg: St.-Petersburg State Chemical-Pharmaceutical Academy; Saint Louis: Missouri Botanical Gerden Press. 772 pp. [In Russian and English] (Егорова T. В. Осоки (Сагех L.) России и сопредельных государств (в пределах бывшего СССР) / отв. ред. А. Л. Тахтаджян; СПб.: С.-Петерб. гос. хим.-фармацевт. акад.; Сент-Луис: Миссурийский ботанический сад, 1999. 772 с.).

Favarger C., Zesiger F., Parnell J. 1993. Jovibarba Opiz In: Flora Europaea. Vol. 1. Psilotaceae to Platanaceae. T. G. Tutin, N. A. Burges, A. O. Chater, J. R. Edmondson, V. H. Heywood, D. M. Moore, D. H. Valentine, S. M. Walters, D. A. Webb (eds). 2nd ed. Cambridge: Cambridge University Press. Pp. 428-429.

Flora Nizhnego Dona (Opredelitel) [Flora of the Lower Don (key for plant identification)]. 1985. Part 2. G. M. Zozulina, V. V. Fedyaeva (eds). Rostov-on-Don: Rostov University Publishing House. 240 pp. [In Russian] (Флора Нижнего Дона (определитель). Ч. 2. Под ред. Г. М. Зозулина, В. В. Федяевой. Ростов-на-Дону: Изд-во Ростовского ун-та, 1985. 240 с.).

Gafurova M. M. 2014. Vascular plants of Chuvash Republic (Flora of the Volga river basin. Vol. III). Togliatti: Kassandra. 333 pp. [In Russian] (Гафурова M. М. Сосудистые растения Чувашской Республики (Флора Волжского бассейна. Т. 3). Тольятти: Кассандра, 2014. 333 с.).

Galium densiflorum Ledeb. in GBIF Secretariat. 2021. GBIF Backbone Taxonomy. Checklist dataset https://doi. org/10.15468/39omei accessed via GBIF.org on 2021-06-10.

Ghahremani F. 2004. The Sections of Astragalus L. With Bifurcating Hairs in Iran. Turkish Journal of Botany. 28: $101-117$.

Glazunov V. A., Nikolaenko S. A. 2015. New data on distribution of Najadaceae in Tyumen Region. Bot. Zhurn. 100(1): 68-70. [In Russian] (Глазунов В. А., Николаенко С. А. Новые сведения о распространении наядовых (Najadaceae) в Тюменской области // Бот. журн., 2015. Т. 100. № 1. С. 68-70).

Global Invasive Species Database. 2013. ISSG Database: Ecology of Najas minor. http://issg.org/database/ species/ecology.asp?si=1560\&fr=1\&sts=\&lang=EN (Accessed 08 November 2020).

Gorchakovskiy P. L. 1966. Flora i rastitelnost vysokogoriy Urala. [Flora and vegetation of the Urals highlands]. Sverdlovsk: Ural branch of the Academy of Sciences of the USSR. 270 pp. [In Russian] (Горчаковский П. Л. Флора и растительность высокогорий Урала. Свердловск: УрФ АН СССР, 1966. 270 с.).

Gorchakovskiy P. L. 1975. Rastitelnyy mir vysokogornogo Urala [Plant world of the high-mountainous Urals]. Moscow: Nauka. 285 pp. [In Russian] (Горчаковский П. Л. Растительный мир высокогорного Урала. М.: Наука, 1975. 285 c.).

Goworuchin W. S. 1937. Flora Urala. Opredelitel rasteniy, obitajushhih na gorah Urala i v ego predgorjah ot beregov Karskogo morja do juzhnyh predelov lesnoj zony [Flora of the Urals. Key to identify plants inhabiting the mountains of the Urals and in its foothills from the shores of the Kara Sea to the southern limits of the forest zone]. Sverdlovsk: Sverdlovsk regional publishing house. 536 pp. [In Russian] (Говорухин В. С. Флора Урала. Определитель растений, обитающих на горах Урала и в его предгорьях от берегов Карского моря до южных пределов лесной зоны. Свердловск: Свердловское обл. изд-во, 1937. 536 с.).

Igoshina K. N. 1966. Flora of tundras and open forests of the Urals. In: The vegetation of the Far Siberian North and Northern Far East. Iss. 6. B. A. Tikhomirov (Ed.). Moscow; Leningrad: Nauka. Pp. 135-223. [In Russian] (Иzoшина К. Н. Флора горных и равнинных тундр и редколесий Урала // Растения севера Сибири и Дальнего Востока. Растительность Крайнего Севера СССР и ее освоение. Вып. 6. М.-Л.: Наука, 1966. С. 135-223).

Illyustrirovannyy opredelitel rasteniy Permskogo kraya [Illustrated key to identify plants of the Perm Region]. 2007. S. A. Ovesnov (Ed.). Perm: Knizhnyi mir. 743 pp. [In Russian] (Иллюстрированный определитель растений Пермского края / Овеснов С. А., Ефимик Е. Г., Козьминых Т. В. [и др.]; под ред. С. А. Овеснова. Пермь: Книжный мир, 2007. 743 с.).

Jersáková J., Malinová T., Jeřábková K., Dötterl S. 2011. Biological flora of the British Isles: Pseudorchis albida (L.) Á. \& D. Löve. Journal of Ecology 99: 1282-1298. DOI: 10.1111/j.1365-2745.2011.01868.x

Kapitonova O. A. 2017. About protection of aquatic and semi-aquatic plants in south of the Tyumen Region. In: Problems of Botany of South Siberia and Mongolia: Proceedings of the 16h International Scientifc and Practical Conference (Barnaul, 5-8 June 2017). Barnaul: Concept. Pp. 306-309. [In Russian] (Капитонова О. А. Об охране 
водных и прибрежно-водных растений на юге Тюменской области // Проблемы ботаники Южной Сибири и Монголии: сб. науч. ст. по материалам XVI междунар. науч.-практ. конф. (г. Барнаул, 5-8 июня 2017 г.). Барнаул: Концепт, 2017. С. 306-309).

Kaplan Z., Symoens J.-J. 2005. Taxonomy, distribution and nomenclature of three confused broad-leaved Potamogeton species occurring in Africa and on surrounding islands. Botanical Journal of the Linnean Society. 148: 329-357. DOI: 10.1111/j.1095-8339.2005.00410.x

Kashina L. I. 1992. Atraphaxis L. In: Flora Sibiri [Flora of Siberia]. T. 5. Salicaceae - Amaranthaceae. I. M. Krasnoborov, L. I. Malyschev (eds). Novosibirsk: Nauka, division sibirica. Pp. 108-109. [In Russian] (Кашина Л. И. Род Atraphaxis L. - Курчавка // Флора Сибири: в 14 т. Т. 5. Salicaceae - Amaranthaceae. Новосибирск: Наука. Сиб. отд-ние, 1992. С. 108-109).

Khozyainova N. V., Glazunov V. A. 2001. Dopolneniya k "Flore Sibiri" po Tobolskomu floristicheskomu rayonu Tyumenskoy oblasti [Additions to the "Flora of Siberia" for the Tobolsk floristic district of the Tyumen Region]. Krylovia. Sibirskiy botanicheskiy zhurnal 3(1): 78-81. [In Russian] (Хозяинова Н. В., Глазунов В. А. Дополнения к «Флоре Сибири» по Тобольскому флористическому району Тюменской области // Krylovia. Сибирский Бот. журн., 2001. Т. 3. № 1. С. 78-81.

Knyazev M. S., Tretyakova A. S., Podgaevskaya E. N., Zolotareva N. V., Kulikov P. V. 2017. An annotated check list of the flora of Sverdlovsk Region. Part II: monocotyledonous plants. Phytodiversity of Eastern Europe 11(3): 4-108. [In Russian] (Князев М. С., Третьякова А. С., Подгаевская Е. Н., Золотарёва Н. В., Куликов П. В. Конспект флоры Свердловской области. Часть 2: однодольные растения // Фиторазнообразие Восточной Европы, 2017. T. 11. № 3. C. 4-108).

Knyazev M. S., Tretyakova A. S., Podgaevskaya E. N., Zolotareva N. V., Kulikov P. V. 2018. Annotated checklist of the flora of Sverdlovsk Region. Part III: dicotyledonous plants (Aristolochiaceae - Monotropaceae). Phytodiversity of Eastern Europe 12(2): 4-95. [In Russian] (Князев М. С., Третьякова А. С., Подгаевская Е. Н., Золотарёва Н. В., Куликов П. В. Конспект флоры Свердловской области. Часть 3: Двудольные растения (Empetraceae Droseraceae) // Фиторазнообразие Восточной Европы, 2018. Т. 12, № 2. C. 4-95). DOI: 10.24411/2072-88162018-10013

Knyazev M. S., Tretyakova A. S., Podgaevskaya E. N., Zolotareva N. V., Kulikov P. V. 2019. Annotated checklist of the flora of Sverdlovsk Region. Part IV: dicotyledonous plants (Empetraceae - Droseraceae). Phytodiversity of Eastern Europe 13(2): 130-196. [In Russian] (Князев М. С., Третьякова А. С., Подгаевская Е. Н., Золотарёва Н. В., Куликов П. В. Конспект флоры Свердловской области. Часть 4: Двудольные растения (Empetraceae Droseraceae) // Фиторазнообразие Восточной Европы, 2019. Т. 13, № 2. С. 130-196). DOI: 10.24411/2072-88162019-10046

Korableva T. P. 1977. Pyrolaceae Dum. In: Flora regionis boreali-orientalis territoriae Europaeae URSS. T. IV. Umbelliferae - Compositae. A. I. Tolmatchev (Ed.). Leninopoli: Nauka, Sectio Leninopoli. Pp. 29-35. [In Russian] (кобелева T. П. Сем. Pyrolaceae Dumort. - Грушанковые // Флора Северо-Востока Европейской части СССР. Т. 4. Umbelliferae - Compositae. Л.: Наука, 1977. С. 29-35).

Korikova N. N., Tyurin V. N. 2018. Rare plants of the Neroyka mountain (Subpolar Ural). In: Ekologiya i geografiya rasteniy i rastitelnykh soobshchestv: materialy IV Mezhdunarodnoy nauchnoy konferentsii [Ecology and geography of plants and plant communities: materials of the IV International Scientific Conference (Yekaterinburg, April 16-19, 2018)]. Yekaterinburg: Publishing house of the Ural University; Humanitarian University. Pp. 461-465. [In Russian] (Корикова Н. Н., Тюрин В. Н. Редкие растения окрестностей горы Неройка (Приполярный Урал) // Экология и география растений и растительных сообществ: материалы IV Междунар. науч. конф. (г. Екатеринбург, 16-19 апреля 2018 г.). Екатеринбург: Изд-во Урал. ун-та; Гуманитарный ун-т, 2018. C. 461-465).

Koropachinskiy I. Yu., Vstovskaya T. N. 2002. Woody plants of the Asian part of Russia. Novosibirsk: Publishing House of SB RAS, Branch “Geo". 707 pp. [In Russian] (Коропачинский И. Ю., Встовская Т. Н. Древесные растения Азиатской России. Новосибирск: Изд-во СО РАН, филиал «Гео», 2002. 707 с.).

Kosachev P. A., Ebel A. L. 2010. Notes on Veronica L. in Siberia. Sist. Zametki Mater. Gerb. Krylova Tomsk. Gosud. Univ. [Systematic notes on the materials of P. N. Krylov Herbarium of Tomsk State University] 102: 9-16. [In Russian] (Косачев П. А., Эбель А. Л. Заметки о верониках Сибири // Сист. зам. Герб. Томск. ун-та, 2010. № 102. C. 9-16).

Krasnaya kniga Chelyabinskoy oblasti: zhivotnyye, rasteniya, griby [The Red Data Book of the Chelyabinsk Region: Animals, Plants, Mushrooms]. 2017a. V. N. Bolshakov (Ed.). Moscow: LLC Reart. 504 pp. [In Russian] (Kpacная книга Челябинской области: животные, растения, грибы. Под общ. ред. В. Н. Большакова. М.: ООО «Реарт», 2017a. 504 c.).

Krasnaya kniga Khanty-Mansiyskogo avtonomnogo okruga - Yugry: zhivotnyye, rasteniya, griby [Red Data Book of the Khanty-Mansi Autonomous Area - Yugra: animals, plants, mushrooms]. Ed. $2^{\text {nd }}$. A. M. Vasin, A. L. Vasina (Ex. eds). Yekaterinburg: Publishing House Basko, 2013. 460 pp. [In Russian] (Красная книга Ханты-Мансийского автономного округа - Югры: животные, растения, грибы. Изд. 2-е. Отв. ред. А. М. Васин, А. Л. Васина. Екатеринбург: Изд-во «Баско», 2013. 460 с.). 
Krasnaya kniga Moskovskoy oblasti (izdaniye vtoroye, dopolnennoye i pererabotannoye) [Red Data Book of the Moscow Region (second edition, supplemented and revised)]. 2008. T. I. Varlygina, V. A. Zubakin, N. A. Sobolev (Ex. eds). Moscow: Tovarishchestvo nauchnykh izdaniy KMK. 828 pp. [In Russian] (Красная книга Московской области (изд. второе, дополн. и переработ.). Отв. ред.: Т. И. Варлыгина, В. А. Зубакин, Н. А. Соболев. М.: Т-во науч. изд. КМК, 2008. 828 с.).

Krasnaya kniga Nizhegorodskoy oblasti. T. 2: Sosudistyye rasteniya, mokhovidnyye, vodorosli, lishayniki, griby [Red Data Book of the Nizhny Novgorod Region. Vol. 2: Vascular plants, bryophytes, algae, lichens, fungi]. $2017 \mathrm{~b}$. 2nd ed., revised and enlarged. S. V. Bakka [and others]; A. V. Chkalov (Ed.). Kaliningrad: Publishing house "ROSTDOAFK". 304 pp. [In Russian] (Красная книга Нижегородской области. Т. 2: Сосудистые растения, моховидные, водоросли, лишайники, грибы. 2-е изд., переработ. и дополн. С. В. Бакка [и др.]; науч. ред. А. В. Чкалов. Калининград: Изд. дом «РОСТ-ДОАФК», 2017. 304 с.).

Krasnaya kniga Penzenskoy oblasti. T. 1: Griby, lishayniki, mkhi, sosudistyye rasteniya [Red Data Book of the Penza Region. T. 1: Mushrooms, lichens, mosses, vascular plants]. 2013. 2nd ed. A. I. Ivanov (Ed.). Penza. 300 pp. [In Russian] (Красная книга Пензенской области. Т. 1: Грибы, лишайники, мхи, сосудистые растения. Изд. 2-е. Ред. А. И. Иванов. Пенза, 2013. 300 с.).

Krasnaya kniga Respubliki Komi [Red Data Book of the Komi Republic]. 2019. S. V. Degteva (Ed.). Syktyvkar: LLC Komi Republican Printing House. 768 pp. [In Russian] (Красная книга Республики Коми. Под ред. С. В. Дёгтевой. Сыктывкар: ООО «Коми республиканская типография», 2019. 768 с.).

Krasnaya kniga Sverdlovskoy oblasti: zhivotnyye, rasteniya, griby [Red Data Book of the Sverdlovsk Region: Animals, Plants, Mushrooms]. 2018. N. S. Korytin (Ed.). Yekaterinburg: LLC “Mir”. 450 pp. [In Russian] (Kpacная книга Свердловской области: животные, растения, грибы. Отв. ред. Н. С. Корытин. Екатеринбург: ООО «Мир», 2018. 450 с.).

Krylov P. N. 1927-1939. Flora Sibiriae occidentalis. Editio secunda et completa Florae altaicae et provinciae Tomskiensis. Vol. I-XII. Tomsk: Published by the Tomsk Branch of the Russian Botanical Society / Tomsk University Publishing House. Pp. 1-3600. [In Russian] (Крылов П. Н. Флора Западной Сибири. Руководство к определению западно-сибирских растений. Вып. 1-12. Томск: Изд. Том. отд-ния Рус. ботан. о-ва / Изд-во Том. ун-та, 1927-1939. 1-3600 с.).

Krylov P. N. 1939. Flora Sibiriae occidentalis. Editio secunda et completa Florae altaicae et provinciae Tomskiensis. Vol. X. Solanaceae - Dipsacaceae. Tomsk: Published by the Tomsk Branch of the Russian Botanical Society / Tomsk University Publishing House Pp. 2401-2627. [In Russian] (Крылов П. Н. Флора Западной Сибири. Руководство к определению западно-сибирских растений. Вып. 10. Solanaceae - Dipsacaceae. Томск: Изд. Том. отдния Рус. ботан. о-ва / Изд-во Том. ун-та, 1939. С. 2401-2627).

Kulikov P. V. 2005.Conspectus florae provinciae Czeljabinskiensis (plantae vasculares). Yekaterinburg, Miass: Geotur. 537 pp. [In Russian] (Куликов П. В. Конспект флоры Челябинской области (сосудистые растения). Екатеринбург, Миасс: Геотур, 2005. 537 с.).

Kulikov P. V. 2010. Opredelitel sosudistykh rasteniy Chelyabinskoy oblasti [Key for vascular plant identification of the Chelyabinsk Region]. Yekaterinburg: Ural Branch of the Russian Academy of Sciences. 969 pp. [In Russian] (Куликов П. В. Определитель сосудистых растений Челябинской области. Екатеринбург: УрО РАН, 2010. 969 c.).

Kulikov P. V. 2014. A new species of Astragalus (Fabaceae) from plateau Ustyurt (Kazakhstan). Bot. Zhurn. 99(9): 1056-1066. [In Russian] (Куликов П. В. Новый вид рода Astragalus (Fabaceae) с плато Устюрт (Казахстан) // Бот. журн., 2014. Т. 99. № 9. С. 1056-1066).

Lisitsyna L. I., Papchenkov V. G., Artemenko V. I. 2009. Flora vodoyemov volzhskogo basseyna. Opredelitel sosudistykh rasteniy [Flora of water bodies of the Volga basin. Key for vascular plants identification]. Moscow: Tovarishchestvo nauchnykh izdaniy KMK. 219 pp. [In Russian] (Лисицына Л. И., Папченков В. Г., Артеменко В. И. Флора водоемов волжского бассейна. Определитель сосудистых растений. М.: Т-во науч. изд. КМК, 2009. 219 c.).

Lovelius O. 1978. Compositio specierum, distributio geographica et cohaerentia oecologica generia Atraphaxix L. (Polygonaceae). In: Novit. Syst. Pl. Vasc. et non Vasc. 1977. Kiev: "Naukova Dumka". Pp. 85-108. [In Russian] (Ловелиус О. Л. Видовой состав, географическое распространение и экологическая приуроченность видов рода Atraphaxis L. (Polygonaceae) // Новости сист. высш. и низш. раст., 1977. Киев: «Наукова думка», 1978. C. 85-108).

Malyschev L. I. 1997. Pyrolaceae In: Flora Sibiri [Flora of Siberia]. T. 11. Pyrolaceae - Lamiacae (Labiatae). Eds. A. V. Polozhij, G. A. Peschkova. Novosibirsk: Nauka, Siberian publishing firm RAN. Pp. 8-14. [In Russian] (Малышев Л. И. Семейство Pyrolaceae - Грушанковые // Флора Сибири: в 14 т. Т. 11: Pyrolaceae - Lamiacae (Labiatae) / Сост. В. М. Доронькин, Н. К. Ковтонюк, В. В. Зуев и др. Новосибирск: Наука. Сибирская издательская фирма РАН. 1997. С. 8-14).

Mamayev S. A., Knyazev M. S., Kulikov P. V., Filippov E. G. 2004. Orkhidnyye Urala: sistematika, biologiya, okhrana [Orchids of the Urals: taxonomy, biology, protection]. Yekaterinburg: Ural Branch of the Russian Academy 
of Sciences. 124 pp. [In Russian] (Мамаев С. А., Князев М. С., Куликов П. В., Филиппов Е. Г. Орхидные Урала: систематика, биология, охрана. Екатеринбург: УрО РАН, 2004. 124 с.).

Martynenko V. A., Gruzdev B. I. 2008. Sosudistyye rasteniya Respubliki Komi [Vascular plants of the Komi Republic]. Syktyvkar. 136 pp [In Russian] (Мартыненко В. А., Груздев Б. И. Сосудистые растения Республики Коми. Сыктывкар, 2008. 136 с.).

Mayevskiy P. F. 2014. Flora sredney polosy yevropeyskoy chasti Rossii [Flora of the middle zone of the European part of Russia]. 11 th ed. Moscow: Tovarishchestvo nauchnykh izdaniy KMK. 635 pp. [In Russian] (Маевский П. Ф. Флора средней полосы европейской части России. 11-е изд. М.: Т-во науч. изд. КМК, 2014. 635 с.).

Melnikov D. G. 2019. The planned border of "Flora of the Urals and adjacent territories". In: Botaniko-geograficheskiye issledovaniya. Kamelinskiye chteniya: sbornik nauchnyykh trudov [Botanical and geographical research. Kamelinsky readings: compedium of scientific works]. S. A. Ovesnov, O. G. Baranova (eds). Perm: Publishing House of the Perm National Research Polytechnic University. Pp. 108-112. [In Russian] (Мельников Д. Г. Планируемые границы «Флоры Урала и прилегающих территорий» // Ботанико-географические исследования. Камелинские чтения: сб. науч. тр. Под ред. С. А. Овеснова, О. Г. Барановой. Пермь: Изд-во Перм. нац. исслед. политехн. ун-та, 2019. С. 108-112).

Melnikov D. G., Knyazev M. S., Baranova O. G. 2018. The Urals need its own "Flora”. In: Botanika v sovremennom mire. Trudy XIV Syezda Russkogo botanicheskogo obshchestva i konferentsii «Botanika v sovremennom mire» [Botany in the modern world. Proceedings of the XIV Congress of the Russian Botanical Society and the conference "Botany in the modern world" (Makhachkala, June 18-23, 2018)]. Vol. 1: Systematics of higher plants. Floristics and geography of plants. Plant protection. Paleobotany. Botanical education. Makhachkala: ALEF. Pp. 163-165.

Merkulowicz N. A. 1941. Najadaceae. In: Flora Uzbekistanica. Vol. 1. R. R. Schreder (Ed.). Taschkent: Editio sectionis Uzbekistanicae Academiae Scientiarum URSS. Pp. 134-135. [In Russian] (Меркулович Н. А. Najadaceae // Флора Узбекистана. Т. 1. Гл. ред. Р. Р. Шредер. Ташкент: Изд-во Узбекист. филиала АН СССР, 1941. C. 134-135).

Midorikawa Sh., Shutoh K., Shiga T. 2020. An easy method of identifying herbarium specimens of Najas minor and N. oguraensis (Hydrocharitaceae). Acta Phytotax. Geobot. 71(1): 55-63. DOI: 10.18942/apg.201915

Moore D. M. 1980. Pseudorchis Seguier. In: Flora Europaea. Vol. 5. Alismataceae to Orchidaceae (Monocotyledones). T. G. Tutin, V. H. Heywood, N. A. Burges, D. M. Moore, D. H. Valentine, S. M. Walters, D. A. Webb (eds). Cambridge: Cambridge University Press. P. 332.

Mosyakin S. L., Fedoronchuk M. M. 1999. Vascular plants of Ukraine. A nomenclatural checklist. Kiev. 346 pp. DOI: $10.13140 / 2.1 .2985 .0409$

Muldashev A. A., Abramova L. M., Golovanov Ya. M. 2017. Konspekt adventivnykh vidov rasteniy Respubliki Bashkortostan [Synopsis of adventive plant species of the Republic of Bashkortostan]. Ufa: Bashkirskaya entsiklopediya. 168 pp. [In Russian] (Мулдашев А. А., Абрамова Л. М., Голованов Я. М. Конспект адвентивных видов растений Республики Башкортостан. Уфа: Башк. энциклопедия, 2017. 168 с.).

Najas minor All. in GBIF Secretariat. 2021. GBIF Backbone Taxonomy. Checklist dataset https://doi. org/10.15468/39omei accessed via GBIF.org on 2021-06-10.

Naumenko N. I. 2008. On the flora and vegetative cover of Southern Zauralye. Kurgan: Kurgan University Press. 512 pp. [In Russian] (Науменко Н. И. Флора и растительность Южного Зауралья: монография. Курган: Изд-во Курганского ун-та, 2008. 512 с.).

Naumenko N. I., Kuzmin I. V., Glazunov V. A. 2011. Additions and corrections to the flora of the Nizhnetavdinsky district of the Tyumen Region and the history of its study. In: IV Tavdinskiye chteniya: Materialy regionalnoy nauchno-prakticheskoy konferentsii [IV Tavdinsky readings: Materials of the regional scientific-practical conference (v. Nizhnyaya Tavda, 3 November 2011)]. Tyumen. Pp. 105-116. [In Russian] (Науменко Н. И., Кузьмин И. В., Глазунов В. $\boldsymbol{A}$. Дополнения и исправления к флоре Нижнетавдинского района Тюменской области и истории ее изучения // IV Тавдинские чтения: Материалы регион. науч.-практич. конф. (с. Нижняя Тавда, 3 ноября 2011). Тюмень, 2011. С. 105-116).

Naumova E. G. 1996. Galium L. In: Flora Sibiri [Flora of Siberia]. T. 12. Solanaceae - Lobeliaceae. A. V. Polozhij, G. A. Peshkova (eds). Novosibirsk: Science. Siberian publishing firm RAN. Pp. 110-124. [In Russian] (Наумова E. Г. Galium L. - Подмаренник // Флора Сибири: в 14 т. Т. 12: Solanaceae - Lobeliaceae / Сост. А. В. Положий, С. Н. Выдрина, В. И. Курбатский и др. Новосибирск: Наука. Сибирская издательская фирма РАН. 1996. С. $110-124)$.

Noskov A. K. 1931. Ufa and its environs (Preliminary report on botanical and geographical research). Acta horti botanici Acad. Scient. (ante Petropolitani) 42(2): 181-209. [In Russian] (Носков А. К. Уфа и ее окрестности (Предварительный отчет о ботанико-географических исследованиях // Тр. Ботан. сада AH CCCP, 1931. T. XLII. Вып. 2. С. 181-209).

Opredelitel vysshikh rasteniy Bashkirskoy ASSR [Key for higher plants identification of the Bashkir ASSR. Brassicaceae - Asteraceae]. 1989. E. V. Kucherov, A. A. Muldashev (Ex. Eds). Moscow: Nauka. 375 pp. [In Russian] 
(Определитель высших растений Башкирской АССР. Сем. Brassicaceae - Asteraceae. Отв. ред. Е. В. Кучеров, А. А. Мулдашев. М.: Наука, 1989. 375 с.).

Opredelitel vysshikh rasteniy Belarusi [Key for higher plants identification of Belarus]. 1999. V. I. Parfenov (Ed.). Minsk: Dizayn PRO. 472 pp. [In Russian] (Определитель высших растений Беларуси. Под ред. В. И. Парфенова. Минск: Дизайн ПРО, 1999, 472 с.).

Opredelitel sosudistykh rasteniy Srednego Urala [Key for vascular plants identification of the Middle Urals]. 1994. P. L. Gochakovsky (Ex. Ed.). Moscow: Nauka. 525 pp. [In Russian] (Определитель сосудистых растений Среднего Урала. Отв. ред. П. Л. Гочаковский. М.: Наука, 1994. 525 с.).

Ovesnov S. A. 1997. Konspekt flory Permskoy oblasti [Synopsis of the flora of the Perm Region]. Perm: Izdatestvo Permskogo universiteta. 252 pp. [In Russian] (Овёснов С. А. Конспект флоры Пермской области. Пермь: Изд-во Перм. ун-та. 1997. 252 с.).

Pinzhenina (Balde) E. A. 2014. The taxonomic characters and its significance for systematics of genus Galium (Rubiaceae). In: Perspektivy razvitiya i problemy sovremennoy botaniki: Materialy III (V) Vserossiyskoy molodezhnoy konferentsii s uchastiyem inostrannykh uchenykh [Development prospects and problems of modern botany: Proceedings of the III (V) All-Russian youth conference with the participation of foreign scientists (November 10-14, 2014, Novosibirsk)]. S. V. Asbaganov (Ex. Ed.). Novosibirsk: Publishing house “Akademizdat”. Pp. 31-33. [In Rissian] (Пинженина (Балде) Е. А. Таксономические признаки и их значение для систематики рода Galium (Rubiaсеае) // Перспективы развития и проблемы современной ботаники: Материалы III (V) Всеросс. молодеж. конф. с участием иностр. ученых (10-14 ноября 2014 г., г. Новосибирск). Отв. ред. С. В. Асбаганов. Новосибирск: Изд-во «Академиздат», 2014. С. 31-33).

Pinzhenina E. A. 2020. Analysis of the ranges of the type section representatives of the genus Galium L. (Rubiaceae Juss.) in Asian Russia. In: Problems of Botany of South Siberia and Mongolia 19(2): 346-351. [In Rissian with English summary] (Пинженина $\boldsymbol{E}$. A. Анализ ареалов представителей типовой секции рода Galium L. (Rubiaceae Juss.) в Азиатской России) // Проблемы ботаники Южной Сибири и Монголии, 2020. Т. 19 , № 2. C. 346-351). DOI: 10.14258/pbssm.2020132

Plantae vasculares rei publicae Mordoviensis (conspectus florae). T. B. Silaeva (Ed.). 2010. Saransk: Editio universitatis Mordoviensis. 352 pp. [In Russian] (Сосудистые растения Республики Мордовия (конспект флоры). Под ред. Т. Б. Силаевой. Саранск: Изд-во Мордов. ун-та, 2010. 352 с.).

Pobedimova E. G. 1958. Galium L. In: Flora SSSR [Flora of the USSR]. T. XXIII. Ed. B. K. Schischkin. Moscow, Leningrad. Editio Academiae scientiarum URSS. Pp. 287-381. [In Russian] (Победимова Е. Г. Подмаренник - Gаlium L. // Флора СССР. Т. 23. М.-Л.: Изд-во АН СССР, 1958. С. 287-381).

Pobedimova E. G. 1978. Galium L. In: Flora partis europaeae URSS. T. III. (Magnoliodpsida (=Dicotyledones). An. A. Fedorov (Ed. Princ.). Leningrad: Nauka. Pp. 100-115. [In Russian] (Победимова Е. Г. Подмаренник - Galium L. // Флора европейской части СССР. Т. 3. / Отв. ред. Ан. А. Федоров. Л.: Наука, 1978. С. 100-115).

Podlech D. 1999. Astragalus L. In: Flora Iberica. Plantas vasculares de la Península Ibérica e Islas Baleares. Vol. VII (I). Leguminosae (partim). S. Talavera, C. Aedo, S. Castroviejo, C. Romero Zarco, L. Sáez, F. J. Salgueiro, M. Velayos (eds.). Madrid: Real Jardín Botánico, CSIC. Pp. 279-338.

Podlech D., Zarre S. H. (with collaboration of Ekici M., Maassoumi A. A. R., Sytin A.). 2013. A taxonomic revision of the genus Astragalus L. (Leguminosae) in the Old World. Vol. 3. Wien: Naturhistorisches Museum. Pp. 1641-2439.

Potamogeton nodosus Poir. in GBIF Secretariat. 2021. GBIF Backbone Taxonomy. Checklist dataset https://doi. org/10.15468/39omei accessed via GBIF.org on 2021-06-10.

Pseudorchis albida (L.) Á. Löve \& D. Löve in GBIF Secretariat. 2021. GBIF Backbone Taxonomy. Checklist dataset https://doi.org/10.15468/39omei accessed via GBIF.org on 2021-06-10.

Rakov N. S., Saksonov S. V., Senator S. A., Vasjukov V. M. 2014. Vascular plants of Ulyanovsk Region (Flora of the Volga river basin. Vol. II). Togliatti: Kassandra. 295 pp. [In Russian] (Раков Н. С., Саксонов С. В., Сенатор C. A., Васюков В. М. Сосудистые растения Ульяновской области (Флора Волжского бассейна. Т. 2). Тольятти: Кассандра, 2014. 295 с.).

Rastitelnyy pokrov i rastitelnyye resursy Polyarnogo Urala [Vegetation cover and plant resources of the Polar Urals]. 2006. Yekaterinburg: Publishing house of the Ural University. 796 pp. [In Russian] (Растительный покров и растительные ресурсы Полярного Урала. Екатеринбург: Изд-во Уральского ун-та, 2006. 796 с.).

Ryabinina Z. N., Knyazev M. S. 2009. Opredelitel sosudistykh rasteniy Orenburgskoy oblasti. [Key for vascular plant identification of the Orenburg Region]. Moscow: Tovarishchestvo nauchnykh izdaniy KMK. 758 pp. [In Russian] (Рябинина 3. Н., Князев М. С. Определитель сосудистых растений Оренбургской области. М.: Т-во науч. изд. КМК, 2009. 758 с.).

Saksonov S. V., Senator S. A. 2012. Guide the Samara flora (1851-2011) (Flora of the Volga River basin. Vol. I). Togliatti: Kassandra. 512 pp. [In Russian] (Саксонов С. В., Сенатор С. А. Путеводитель по Самарской флоре (1851-2011) (Флора Волжского бассейна. Т. 1). Тольятти: Кассандра, 2012. 512 с.). 
Salix myrsinites L. in GBIF Secretariat. 2021. GBIF Backbone Taxonomy. Checklist dataset https://doi. org/10.15468/39omei accessed via GBIF.org on 2021-06-10.

Shaulo D., Artemov A., Doduk A., Molokova N. 2006. The floristic findings in Tyva Republic. Turczaninowia 9, 3: 90-98. [In Russian]. (Шауло Д. Н., Артемов И. А., Додук А. Д., Молокова Н. И. Флористические находки в Республике Тыва // Turczaninowia, 2006. Т. 9, № 3. С. 90-98).

Shcherbakov A. V., Khlyzova N. Yu., Vargot E. V. 2008. Potamogeton nodosus Poir. (Potamogetonaceae) in Middle Russia. Byull. Moskovsk. Obshch. Isp. Prir., Otd. Biol. [Bull. Moscow Soc. Natur. Biol. Ser.] 113, 6: 62-64. [In Russian] (Щербаков А. В., Хлызова Н. Ю., Варгот Е. В. Potamogeton nodosus Poir. (Potamogetonaceae) в Средней России // Бюл. МОИП. Отд. биол., 2008. Т. 113, № 6. С. 62-64).

Skvortsov A. K. 1960. About the species of the Ramischia genus. Vestnik Moskovskogo universiteta. Seriâ 6, Biologiâ, Pochvovedeniye [Vestnik of the Moscow University. Series VI. Biology, Soil Science] 1: 47-53. [In Russian] (Скворцов A. К. О видах рода Рамишия // Вестник Московского университета. Сер. VI. Биология, Почвоведение, 1960. № 1. С. 47-53).

Skvortzov A. K. 1966. Salix L. In: Flora Arctica USSR. Revisio critica plantarum vascularum in regione Arctica Unionis Rerum Publicarum Sovieticarum Socialisticarum sponte crescentium. Fasc. V. Salicaceae - Portulacaceae. A. I. Tolmachev (Ed.). Mosquae, Leninopoli: Editio "Nauka". Pp. 11-118. [In Russian] (Скворцов A. К. Salix L. - Ива // Арктическая флора СССР. Критический обзор сосудистых растений, встречающихся в арктических районах СССР. Вып. 5. Salicaceae - Portulacaceae. Под ред. А. И. Толмачева. М.-Л.: Наука, 1966. С. 11-118).

Skvortsov A. K. 1980. Pyrolaceae Dumort. In: Flora Arctica USSR. Revisio critica plantarum vascularum in regione Arctica Unionis Rerum Publicarum Sovieticarum Socialisticarum sponte crescentium. Fasc. VIII. Geraniaceae - Scrophulariaceae. A. I. Tolmatchev, B. A. Yurtsev (eds). Leninopoli: Editio "Nauka”. Pp. 95-105. [In Russian] (Скворцов A. К. Сем. Pyrolaceae Dumort. - Грушанковые // Арктическая флора СССР. Критический обзор сосудистых растений, встречающихся в арктических районах СССР. Вып. 8. Salicaceae - Portulacaceae. Под ред. А. И. Толмачева и Б. А. Юрцева. Л.: Изд-во «Наука», Ленинград. отд-ние, 1980. С. 95-105).

Skvortsov A. K. 1981. Pyrolaceae Dum. In: Flora partis europaeae URSS. T. V. Magnoliophyta (=Angiospermae), Magnoliopsida (=Dicotyledines). An. A. Fedorov (Ed. Princ.). Leningrad: Nauka. Pp. 52-57. [In Russian] (Скворцов $\boldsymbol{A}$. K. Сем. Pyrolaceae Dum. - Грушанковые // Флора Европейской части CCCP. Т. 5. Покрытосеменные, Двудольные. Л.: Наука, 1981. С. 52-57).

Skvortsov A. K. 1999. Willows of Russia and adjacent countries. Taxonomical and geographical revision. Univ. Joensuu Fac. Math. Nat. Sci. Rep. Ser. 39: 1-307.

Suizev P. V. 1912. Florae uralensis in finibus provinciae Permensis conspectus. In: Materialy k poznaniyu fauny $i$ flory Rossiyskoy imperii [Materials for the knowledge of the fauna and flora of the Russian Empire. Botanical department]. Iss. 7. Moscow: Tipo-litografiya Tovarishchestva I. N. Kushnerev i Ko. 206 pp. [In Russian] (Сюзев П. В. Конспект флоры Урала в пределах Пермской губернии // Материалы к познанию фауны и флоры Российской империи. Отд. ботан. Вып. 7. М.: Типо-литография Товарищества И. Н. Кушнерев и Ко., 1912. 206 с.).

Sytin A. K. 2009. Astragaly (Astragalus L., Fabaceae) Vostochnoy Yevropy i Kavkaza: sistematika, geografiya, evolyutsiya [Astragalus L. (Fabaceae) of Eastern Europe and the Caucasus: taxonomy, geography, evolution]: Abstract of dissertation ... Doctor of Biological Sciences. St. Petersburg. 48 pp. [In Russian] (Сытин А. К. Астрагалы (Astragalus L., Fabaceae) Восточной Европы и Кавказа: систематика, география, эволюция: Автореф. дис. ... д-ра биол. наук. СПб., 2009. 48 с.).

Tabaka L., Gavrilova G., Fatare I. 1988. Flora sosudistykh rasteniy Latviyskoy SSR [Flora of vascular plants of the Latvian SSR]. Riga: Zinatne. 195 pp. [In Russian] (Табака Л., Гаврилова Г., Фатаре И. Флора сосудистых растений Латвийской ССР. Рига: Зинатне, 1988. 195 с.).

Tarasova E. M. 2007. Flora Vyatskogo kraya. Chast 1. Sosudistyye rasteniya [Flora of the Vyatka Territory. Part 1. Vascular plants]. Kirov: OAO "Kirovskaya oblastnaya tipografiya”. 440 pp. [In Russian] (Tарасова Е. М. Флора Вятского края. Ч. 1. Сосудистые растения. Киров: ОАО «Кировская областная типография», 2007.440 с.).

The World Checklist of Vascular Plants (WCVP). [2021]. URL: https://wcvp.science.kew.org (Accessed 18 Juni 2021).

Tikhomirov Val. N. 2015. New combination in the genus Caulinia Willd. (Hydrocharitaceae). Novosti sistematiki vysshikh rasteniy [Novit. Syst. Pl. Vasc.] 46: 25-28. [In Russian] (Тихомиров Вал. Н. Новая комбинация в роде Caulinia Willd. (Hydrocharitaceae) // Новости сист. высш. раст., 2015. T. 46. С. 25-28).

Triest L. 1988. A revision of the genus Najas L. (Najadaceae) in the Old World. Brussels: Academie Royale des Sciences d'Outre-Mer. $172 \mathrm{pp}$.

Tyurin V. N., Baykalova A. S. 2012. New finds of rare plants in the Northern Urals (Khanty-Mansi Autonomous Area - Yugra). In: Biologicheskoye raznoobraziye rastitelnogo mira Urala i sopredelnykh territoriy: materialy Vserossiyskoy konferentsii s mezhdunarodnym uchastiyem [Biological diversity of the flora of the Urals and adjacent territories: materials of the All-Russian conference with international participation (Yekaterinburg, May 28 - June 1, 2012)]. Yekaterinburg: Goshchitskiy. Pp. 96-97. [In Russian] (Тюрин В. Н., Байкалова А. С. Новые находки редких растений на Северном Урале (ХМАО - Югра) // Биологическое разнообразие растительного мира Урала и 
сопредельных территорий: материалы Всеросс. конф. с междунар. участием (г. Екатеринбург, 28 мая - 1 июня 2012 г.). Екатеринбург: Гощицкий, 2012. С. 96-97).

Tzvelev N. N. 1979. Najas L. In: Flora partis europaeae URSS. T. IV. Magnoliophyta (= Angiospermae), Magnoliopsida (= Dicotyledines), Liliopsida (= Monocotyledones). An. A. Fedorov (Ed. Princ.). Leningrad: Nauka. Pp. 199-200. [In Russian] (Цвелев H. Н. Род Наяда - Najas L. // Флора Европейской части СССР. Т. 4. Покрытосеменные, Двудольные, Однодольные. Л.: Наука, 1979. С. 199-200).

Tzvelev N. N. 1986. Note de generis Galium L. (Rubiaceae) speciebus nonnullis florae URSS. Novosti sistematiki vysshikh rasteniy [Novit. Syst. Pl. Vasc.] 23: 153-159. [In Russian] (Цвелев Н. Н. Заметки о некоторых видах подмаренника (Galium L., Rubiaceae) флоры СССР // Новости сист. высш. раст., 1986. Т. 23. С. 153-159).

Tzvelev N. N. 1987. Galium L. In: Flora Arctica USSR. Revisio critica plantarum vascularum in regione Arctica Unionis Rerum Publicarum Sovieticarum Socialisticarum sponte crescentium. Fasc. X. Rubiaceae - Compositae. B. A. Yurtsev (Ed.). Leninopoli: Editio "Nauka” section Leninopoli. Pp. 11-118. [In Russian] Цвелев Н. Н. Galium L. - Подмаренник // Арктическая флора СССР. Вып. 10. Семейства Rubiaceae - Compositae. Ред. Б. А. Юрцев. Л.: Наука, 1987. С. 8-23).

Tzvelev N. N. 1996. Atraphaxis L. In: Flora Europae Orientalis. T. IX. Magnoliophyta (= Angiospermae), Magnoliopsida (= Dicotyledines). N. N. Tzvelev (Ed. Princ.). Petropoli: Mir i Semia-XCV. Pp. 151-152. [In Russian] (Цвелев Н. Н. Род Курчавка - Atraphaxis L. // Флора Восточной Европы. Т. 9. Покрытосеменные, Двудольные. СПб.: Мир и семья-95, 1996. С. 151-152).

Varlygina T. I., Vakhrameeva M. G., Tatarenko I. V. 2014. Orchids of Russia (biology, ecology and protection). Moscow: Tovarishchestvo nauchnykh izdaniy KMK. 437 pp. [In Russian] (Варльгина Т. И., Вахрамеева М. Г., Татаренко И. В. Орхидные России (биология, экология, охрана). М.: Т-во науч. изд. КМК, 2014. 437 с.).

Vasilyeva A. N. 1961. Astragalus subgenus Calycocystis Bge. In: Flora Kazakhstana [Flora of Kazakhstan]. Vol. 5. N. V. Pavlov (Ch. Ed.). Alma-Ata: Publishing house of the Academy of Sciences of the Kazakh SSR. Pp. 299-330. [In Russian] (Васильева A. H. Astragalus подрод Calycocystis Bge. // Флора Казахстана. Т. V. Гл. ред. Н. В. Павлов. Алма-Ата: Изд-во АН КазССР, 1961. С. 299-330).

Vasilyeva L. I. 1987. Astragalus L. In: Flora partis europaeae URSS. T. VI. Magnoliophyta (= Angiospermae), Magnoliopsida (= Dicotyledines). An. A. Fedorov (Ed. Princ.). Leningrad: Nauka. Pp. 47-76. [In Russian] (Bacuльева Л. И. Род Астрагал - Astragalus L. // Флора Европейской части СССР. Т. 4. Покрытосеменные, Двудольные. Л.: Наука, 1987. С. 47-76).

Vasjukov V. M., Saksonov S. V. 2020. Check-list of the flora of Penza Region (Flora of the Volga River basin. Vol. IV). S. V. Saksonov (Ed.). Togliatti: Anna. 211 pp. [In Russian] (Васюков В. М., Саксонов С. В. Конспект флоры Пензенской области (Флора Волжского бассейна. Т. 4). Тольятти: Анна, 2020. 211 c.).

Veronica agrestis L. in GBIF Secretariat. 2021. GBIF Backbone Taxonomy. Checklist dataset https://doi. org/10.15468/39omei accessed via GBIF.org on 2021-06-10.

Walters S. M., Webb D. A. 1972. Veronica L. In: Flora Europaea. Vol. 3. Diapensiaceae to Myoporaceae. Tutin T. G., Heywood V. H., Burges N. A., Moore D. M., Valentine D. H., Walters S. M., Webb D. A. (eds.). Cambridge: Cambridge Unversity Press. Pp. 242-251.

Yelenevsky A. G. 1978. Sistematika i geografya veronik SSSR i prilezhashchikh stran [Systematics and geography of the Veronica of the USSR and adjacent countries]. Moscow: Nauka. 259 pp. [In Russian] (Еленевский А. Г. Систематика и география вероник СССР и прилежащих стран. М.: Наука, 1978. 259 с.).

Zasukha T. A., Likhovidova T. F. 2001. Rare plants of the Tyumen Region according to the results of the expedition "Tyumen forest-steppe - 2000". In: Yezhegodnik Tyumenskogo oblastnogo krayevedcheskogo muzeya - 2000 [Yearbook of the Tyumen Regional Museum of Local History - 2000]. Tyumen. Pp. 340-348. [In Russian] (3acyxa T. A., Лиховидова T. Ф. Редкие растения Тюменской области по результатам экспедиции «Тюменская лесостепь - 2000» // Ежегодник Тюменского областного краеведческого музея - 2000. Тюмень, 2001. С. 340-348). 